\title{
Peran Strategis Pesantren, Madrasah dan Sekolah Islam di Indonesia
}

\author{
Sri Haningsih ${ }^{1}$
}

\begin{abstract}
Abstrak
Peran pesantren telah lama diakui oleh masyarakat, demikian halnya dengan madrasah dan sekolah Islam misalnya tentang peradaban. Kepiawaian pesantren, madrasah dan sekolah Islam dalam memformulakan pemahaman dan pemikirannya sehingga melahirkan kultur yang mengadabkan manusia adalah potensi riil pesantren, madrasah dan sekolah Islam. Di era global kepiawaian, kultur dan peran strategis itu harus menjadi lebih dimunculkan, atau dituntut untuk dilahirkan kembali

Pesantren, madrasah dan sekolah Islam mempunyai reputasi tersendiri sebagai lembaga yang bercirikan agama Islam. Pertama, sebagai lembaga pendidikan. Kedua, sebagai lembaga lembaga sosial kemasyarakatan. Sebagai lembaga pendidikan karena pesantren madrasah dan sekolah Islam umumnya menyelenggarakan pendidikan. Bahkan karena memiliki ciri khusus yang membedakannya dengan penyelenggaraan pendidikan lain.

Sebagai lembaga sosial kemasyarakatan dibuktikan dengan diharapkannya kehadiran pesantren, madrasah dan sekolah Islam dalam masyarakat. Kehadiran di sini dimaksudkan dalam rangka changing and developing masyarakat. Pesantren, madrasah dan sekolah Islam di sini dianggap sebagai lambang permanensies seorang kiyai di komunitas, atau daerah tertentu. Di bidang ini pesantren, madrasah dan sekolah Islam sangat dikagumi karena pandai merubah perilaku masyarakat, memotivasi, atau melakukan perubahan-perubahan terhadapnya sekalipun terdapat keluhan akan adanya pesantren yang bersifat eklusif, tertutup dengan masyarakat lingkungannya, namun umumnya masyarakat sekitar pesantren mengalami perkembangan yang lebih baik dari sebelumnya.
\end{abstract}

Kata kunci : peran, pesantren, madrasah, dan sekolah Islam.

${ }^{1}$ Dosen Fakultas Ilmu Agama Islam Universitas Islam Indonesia. 


\section{A. Pendahuluan}

Pesantren merupakan institusi yang banyak dipuji orang, khususnya masyarakat muslim, demikian juga dengan keberadaan Madrasah dan Sekolah Islam di Indonesia. Namun di saat yang sama sering pula mendapat kecaman dan dilabelkan sebagai institusi yang banyak "menghambat" kemajuan Islam. Kontroversi mengenai pesantren seperti itu secara tidak langsung telah menempatkan pesantren sebagai institusi yang cukup penting untuk selalu diperhatikan. Pandangan positif akan menempatkan kontroversi tersebut sebagai peluang untuk memperkuat peran pesantren itu sendiri.

Sama halnya Madrasah sebagai lembaga pendidikan Islam yang dikelola oleh Departemen Agama, selama ini masih dipandang rendah kualitasnya oleh sebagian masyarakat. Bahkan rentang waktu perjalanan sekolah yang bernama madrasah di bumi pertiwi ini (Indonesia) sangat panjang, dapat dikatakan hampir sama dengan irama dinamika dunia pendidikan di Indonesia. Seiring dengan perubahan dan perkembangan zaman, kemajuan ilmu pengetahuan dan teknologi serta globalisasi, maka upaya-upaya yang ditujukan untuk mengembangkan kualitas agar citra sekolah ini tidak selalu menjadi nomor dua, setelah sekolah umum yang lain, banyak hal yang bisa dilakukan oleh stakeholder madrasah.

Sejalan dengan perkembangan global, pendidikan Islam menghadapi tantangan manajerial yang cukup mendasar. Harapan dari berbagai pihak agar pendidikan dikelola dengan pola "industri pendidikan" merupakan salah satu perkembangan yang muncul dalam era kompetitif saat ini. Manajemen pendidikan tidak lagi bisa dianggap sebagai "manajemen sosial" yang bebas dari keharusan pencapaian target dan dikendalikan oleh subyek yang berwawasan "sempit", misalnya dengan pendekatan kekeluargaan seperti yang penulis jumpai di sebagian pesantren di Indonesia

Sesuatu yang dapat dikembangkan mengenai peran madrasah, pesantren bahkan sekolah Islam sekalipun, adalah pada peran strategisnya dalam mengelola pola manajemen strategik yang dapat didefinisikan sebagai sekumpulan keputusan dan tindakan yang menghasilkan rumusan (formulasi) dan pelaksanaan (implementasi) rencana-rencana untuk mencapai sasaran-sasaran perusahaan dalam hal ini disebut dengan Madrasah, Pesantren dan Sekolah Islam (Agus Maulana, 1997: 20).

Sesuatu yang dapat dikembangkan dalam pengelolaan 
pendidikan Islam ( pesantren, madrasah dan sekolah Islam) adalah pola manajemen srategikyang dapat didefinisikan sebagai sekumpulan keputusan dan tindakan yang menghasilkan perumusan (formulasi) dan pelaksanaan (implementasi) rencana-rencana untuk mencapai sasaran-sasaran perusahaan dalam hal ini disebut madrasah (Agus Maulana, 1997: 20)

Dalam konteks pendidikan pesantren, madrasah dan sekolah Islam, apabila penerapan "manajemen instruksional" dirumuskan dalam pola-pola praktis yang kaku oleh pemegang kebijakan, akan mengakumulasikan kerawanan masalah. Seperti proses pembelajaran yang kurang memadai, pengembangan sumber daya manusia (SDM) yang tidak profesional dan lain sebagainya. Membiarkan pola seperti ini berkembang (tanpa ada solusi alternatif menuju perkembangan pesantren, madrasah dan sekolah Islam ke depan) pada saatnya akan mengancam eksistensi pesantren, madrasah dan sekolah Islam itu sendiri. Yang terpenting dari semua ini dalam melaksanakan pengelolaan manajemen madrasah terutama pada perannya yang strategis adalah dengan melakukan refleksi dan evaluasi terhadap seluruh potensi yang dimiliki stakeholder dan kemudian secara bersama menyusun program dan rencana pengembangan pesantren, madrasah dan sekolah Islam secara bertahap serta meneguhkan kembali komitmen stakeholder kepada pentingnya pendidikan Islam (madrasah) dalam rangka mempersiapkan subyek didik yang cerdas, bermoral dan memiliki ketrampilan, sehingga dapat memberikan kontribusi pemikiran perkembangan zaman.

Sekilas apabila diperhatikan, era globalisasi yang dijumpai masyarakat ternyata lebih memperkuat perhatian orang terhadap pesantren. Di antara penyebabnya adalah dimungkinkan karena adanya semangat untuk mencari pendidikan alternatif . Era global seakan mengharuskan seseorang atau bahkan kepada komunitas masyarakat secara luas untuk mencari , menggali dan mengembangkan pendidikan alternatif tersebut dan sekaligus untuk memperbesar peluang keunggulan terutama yang terkait dengan peran pesantren ,madrasah dan sekolah Islam yang ada di Indonesia ini.

Dalam tulisan ini penulis kemukakan beberapa poin sebagai berikut: 1) pesantren sebagai akar sejarah pendidikan Islam di Indonesia , 2) eksistensi pesantren, madrasah dan sekolah Islam, 3) Reaktualisasi peran strategis pesantren madrasah dan sekolah Islam 


\section{B. Pesantren sebagai Akar sejarah pendidikan Islam di Indonesia}

Berbicara mengenai akar sejarah pendidikan Islam di Indoensia tidak bisa dilepaskan dari pesantren. Karena Pesantren dianggap sebagai sistem pendidikan asli Indonesia (Haedari Amin, 2007: 34) sekalipun demikian informasi-informasi lain membuktikan bahwa sistem pendidikan pesantren, madrasah, merupakan adaptasi dari sistem pendidikan yang telah dikembangkan sebelumnya. Satu informasi mengatakan bahwa, pesantren, madrasah dan sekolah Islam seperti dikemukakan pendapat pertama yaitu merupakan kelanjutan dan penyempurnaan dari praktik pendidikan pra-Islam atau masa kekuasaan Hindu Budha, Nurcholis Madjid setuju dengan pendapat ini. Sebagaimana disebutkan bahwa pesantren memiliki hubungan historis dengan lembaga pendidikan pra-Islam yang sudah ada sejak masa kekuasaan Hindu Budha, lalu Islam meneruskan dan meng-Islamkannya (Haedari Amin, 2007: 34).

Dari penamaan pesantren sendiri terkait dengan terminologi yang ada di kalangan Hindu. Kata pesantren berakar dari kata santri dengan awalan "pe" dan akhiran "an". Menurut C.C.Berg istilah tersebut berasal kata India Shastri, berarti orang-orang yang tahu buku-buku suci Agama Hindu, atau seorang sarjana ahli kitab suci Agama Hindu. Kata Shastri sendiri berasal dari kata shastra yang berarti buku-buku suci, buku-buku Agama atau pengetahuan. Pendapat kedua menyatakan bahwa pesantren memiliki hubungan historis dengan Timur Tengah. Terkait dengan pengaruh Timur Tengah ini sudah banyak yang membuktikan terutama mereka yang melakukan ibadah haji di Mekah dan Madinah. Mekah dan Madinah bagi ulama Indonesia tidak semata tempat untuk melakukan ibadah haji tetapi tempat untuk mencari ilmu, terutama dengan menghadiri pengajian di Masjidil Haram dan Masjid Nabawi. Adanya perbedaan pendapat ini tidak berarti pendapat satu yang benar, sementara pendapat lainnya salah. Kedua pendapat ini saling mengisi dan pesantren memang tidak bisa dilepaskan dari unsur-unsur Hindu yang sudah lebih awal ada di Indonesia dan unsur-unsur Islam Timur Tengah di mana Islam berasal (Haedari Amin, 2007: 34).

Bertitik tolak dari akar sejarah pesantren atau sebut saja asalusul pesantren tidak bisa dipisahkan dari sejarah pengaruh Walisongo abad 15-16 di Jawa. Pesantren merupakan lembaga pendidikan Islam yang unik di Indonesia. Walisongo adalah tokoh-tokoh penyebar Islam di Jawa abad 16 - 15 yang telah berhasil mengkombinasikan aspek-aspek sekuler dan spiritual dalam memperkenalkan Islam 
pada masyarakat. Keunikan yang dimaksud adalah hampir semua pesantren di Indonesia ini dalam mengembangkan pendidikan kepesantrenannya berkiblat pada ajaran Walisongo. Misal pondok pesantren Nahdlatul Wathan di Pancor Lombok Timur NTB yang saat ini santrinya lebih dari sepuluh ribu orang (Mas'ud Abdurrahman, 2002: 4) dan pondok pesantren yang lainnya yang tersebar di Pulau Jawa. Sedangkan Maksum menyebutkan bahwa akar sejarah atau asal usul lembaga pendidikan Islam misal madrasah adalah merupakan prestasi abad kelima Hijriyah. Madrasah-madrasah yang timbul dalam Islam, tidak dikenal pada masa-masa sahabat dan tabi'in, melainkan sesuatu yang baru setelah 400 tahun sesudah Hijriyah (Maksum, 1999: 60)

Mengawali asal usul pesantren atau akar sejarah pesantren sama halnya dengan membahas sejarah madrasah dan sekolah Islam, karena ketiga lembaga pendidikan ini bernuansa religius atau dengan kata lain fokus studinya keagamaan di samping studi yang lain yang mendukung visi misi ketiga lembaga tersebut juga menjadi program pembelajarannya.

Perkembangan dari pesantren ke madrasah muncul pada awal abad 20, sebagai akibat dari kurang puas terhadap sistem pesantren ( waktu itu ) yang dianggap sempit dan terbatas pada pengajaran ilmu fardlu 'ain (Mas'ud Abdurrahman, 2002: 241) , terdapat dua hal yang melatar belakangi tumbuhnya sistem madrasah di Indonesia, pertama adalah faktor pembaharuan Islam dan kedua respon terhadap politik pendidikan Hindia Belanda. Kemunculan dan perkembangan madrasah tidak bisa dilepaskan dari gerakan pembaharuan Islam dan kemudian dikembangkan oleh organisasi-organisasi Islam baik di Jawa, Sumatera maupun Kalimantan. Oleh karena itu pendidikan dipandang sebagai aspek strategis dalam membentuk pandangan keislaman masyarakat . Dalam kenyataannya, pendidikan yang terlalu berorientasi pada ilmu-ilmu agama ubudiyyah, sebagaimana ditunjukkan dalam pendidikan di masjid, surau dan pesantren, pandangan keislaman masyarakat agaknya kurang memberikan perhatian kepada masalah-masalah sosial, politik, ekonomi dan budaya, untuk melakukan pembaharuan terhadap pandangan dan tindakan masyarakat itu langkah strategis yang harus ditempuh adalah memperbaharui sistem pendidikannya.

Para ahli dimana pun juga, sepakat bahwa sistem pendidikan yang terkait perlu diperbaharui secara berkesinambungan, atas pemahaman tersebut pakar pendidikan mengambil langkahlangkah menuju perbaikan sistem pendidikan tradisional menuju 
sistem pendidikan modern yang dilengkapi dengan pola manejemen sebagai standar mutu. Bagi masyarakat luas, dengan tujuan supaya madrasah tidak dianggap sebagai salah satu pendidikan yang "bercirikan" tradisional, sehingga kiat-kiat untuk menepis anggapan masyarakat tersebut di atas diperlukan manajemen yang tertata dalam sistem pendidikan modern

\section{Eksistensi Madrasah dan Sekolah Islam}

Madrasah sebagai lembaga pendidikan Islam di Indonesia relatif lebih muda dibanding pesantren. Lahir pada abad 20 dengan munculnya madrasah Manbaul Ulum Kerajaan Surakarta tahun 1905 dan Sekolah Adabiyah yang didirikan oleh Syekh Abdullah Ahmad di Sumatera Barat tahun 1909. Madrasah berdiri atas inisiatif dan realisasi dari pembaharuan sistem pendidikan Islam yang telah ada. Menarik untuk diamati mengapa sistem pendidikan pesantren sendiri justru tidak bersifat statis, tetapi selalu mengalami pertumbuhan seiring dengan perubahan masyarakat yang terjadi. Demikian juga madrasah dan sekolah Islam di Indonesia selalu melakukan terobosan-terobosan guna mempertahankan eksitensinya (Mas'ud Abdurrahman, 2002: 226) .

Pembaharuan tersebut menurut Mastuhu, meliputi tiga hal, yaitu: (1)Usaha menyempurnakan sistem pendidikan pesantren, (2) Penyesuaian dengan sistem pendidikan Barat, dan (3) Upaya menjembatani antara sistem pendidikan tradisional pesantren dan sistem pendidikan Barat.

Madrasah sebagai lembaga pendidikan Islam, kini ditempatkan sebagai pendidikan sekolah dalam sistem pendidikan nasional. Di dalam salah satu diktum surat keputusan bersama (SKB) tiga menteri (Menteri Agama, Menteri Pendidikan dan Menteri Dalam Negeri) disebutkan perlunya diambil langkah-langkah untuk meningkatkan mutu pendidikan pada madrasah agar lulusan dari madrasah dapat melanjutkan ke sekolah-sekolah umum, dari sekolah dasar sampai perguruan tinggi (Mastuhu, 1999: 226).

Aktivitas yang berorientasi pada tujuan, perlu dicapai melalui jalan menetapkan hubungan tertentu antara sumber daya yang tersedia (sumber daya material dan moneter). Hubungan tersebut berkembang dengan sebuah pola yang berubah secara konstan yang merefleksikan fakta tentang bagaimana orang-orang bekerja satu sama lain, dan bagaimana mereka dipengaruhi satu sama lain dalam kehidupan keorganisasian mereka. 
Tindakan bekerja melalui pihak lain, untuk mencapai sasaransasaran keorganisasian. Untuk memperoleh manfaat hasil yang maksimum baik dari bakatnya sendiri maupun bakat pihak lainnya diperlukan melalui pembagian kerja, penugasan tanggung jawab bidang-bidang terbatas kepada individu atau kelompok.

Keterlibatan aktif dengan keputusan-keputusan, evaluasi dan seleksi alternatif atau problem-problem keputusan manajemerial. Dalam jangka panjang seluruh masa depan suatu lembaga pendidikan (madrasah) misalnya bergantung pada tingkat hingga di mana keputusan-keputusan "tepat" diambil oleh para manajer.

Sistem pendidikan madrasah di masa akan datang, diharapkan merupakan suatu "industri" dalam arti bahwa pendidikan memerlukan pengelolaan yang professional agar "rate of returns" dari industri pendidikan itu sama atau lebih baik dari investasi dalam sektor ekonomi lainnya.

Untuk memperkuat eksistensi Madrasah, pemerintah mengeluarkan kebijakan berupa Keputusan Presiden No. 34 Tahun 1972 tentang "Tanggung jawab Fungsional Pendidikan dan Latihan ". Isi keputusan ini pada intinya menyangkut tiga hal sebagai berikut (Maksum, 1999: 146):

1. Menteri Pendidikan dan Kebudayaan bertugas dan bertanggungjawab atas pembinaan pendidikan umum dan kejuruan

2. Menteri Tenaga Kerja betugas dan bertanggung jawab atas pembinaan latihan keahlian dari kejuruan tenaga kerja bukan pegawai negeri

3. Ketua Lembaga Administrasi Negara bertugas dan bertanggung jawab atas pembinaan pendidikan dan latihan khusus untuk pegawai negeri

Dua tahun berikutnya, Keppres itu dipertegas dengan Inpres No. 15 Tahun 1974 yang mengatur realisasinya. Bagi Departemen Agama yang mengelola pendidikan Islam, termasuk madrasah, Keputusan ini menimbulkan "masalah". Dalam Tap MPRS No. 27 Tahun 1966 dinyatakan bahwa agama merupakan salah satu unsur mutlak dalam pencapaian tujuan Nasional. Selain itu, dalam Tap MPRS No. 2 Tahun 1960 ditegaskan bahwa madarasah adalah lembaga pendidikan otonom di bawah pengawasan Menteri Agama. Berdasarkan ketentuan ini, maka Departemen Agama menyelenggarakan pendidikan madrasah tidak saja yang bersifat keagamaan dan umum, tetapi juga yang bersifat kejuruan. Dengan Keppres No.34 Tahun 
1972 dan Inpres No.15 Tahun $1974 \mathrm{itu}$, penyelenggaraan pendidikan umum dan kejuruan menjadi sepenuhnya berada di bawah tanggung jawab Departemen Pendidikan dan Kebudayaan.

Secara implisit ketentuan ini mengharuskan diserahkannya penyelenggaraan pendidikan madrasah yang sudah menggunakan kurikulum nasional kepada Kementerian Pendidikan dan Kebudayaan(sekarang Departemen Pendidikan Nasional). Secara yuridis, keberadaan madrasah dijamin oleh undang-undang SKB tiga menteri (menag, Mendikbud dan Mendagri) Tahun 1975 kedudukan madrasah sama dan sejajar dengan sekolah formal lainnya. Demikian juga dalam Undang-Undang Sistem Pendidikan Nasional Nomor 2 Tahun 1989 ditegaskan ulang bahwa madrasah adalah sekolah umum yang berciri khas agama Islam. Kurikulum yang digunakan pun secara umum mengacu kepada kurikulum Dinas dan ditambah kurikulum agama yang dikeluarkan oleh Depag. Oleh karena itu secara teoritis, madrasah seharusnya mampu memberikan nilai lebih bagi para siswanya dibanding sekolah umum (Mifathul Haq, 2002: 26)

Yang menjadi persoalan di sini adalah "apa yang dicari " pesantren, madrasah dan sekolah Islam di Indonesia itu memang ada? Dan bagaimana eksistensinya tersebut. Seberapa tinggi peluang untuk menjadikannya sebagai "alternatif" atau sebagai "keunggulan "? Persoalan tersebut disebabkan madrasah tidak hanya menawarkan peserta didiknya memiliki kematangan intelektual semata melainkan juga memiliki kematangan mental dan spiritual.

\section{Reaktualisasi Peran strategis Pesantren, Madrasah dan Sekolah Islam}

Sudah banyak diketahui bahwa peran pesantren secara konvensional adalah melakukan proses transfer ilmu agama Islam, mencetak kader-kader ulama', dan mempertahankan tardisi. Dalam perkembangan modern, pesantren, madrasah dan sekolah Islam menghadapi tantangan baru, di mana ketiga lembaga Islam tersebut tidak bisa mengelak dari proses modernisasi itu. Dampak dari modernisasi setidaknya mempengaruhi pesantren, madrasah dan sekolah Islam tersebut dari berbagai aspeknya . Di antaranya adalah sistem kelembagaan, orientasi hubungan kiyai-santri, kepemimpinan dan peran pesantren, madrasah dan sekolah Islam.

Orientasi peran pesantren, madrasah dan sekolah Islam sangat dipengaruhi oleh faktor internal pesantren, terutama pandangan 
dunia kiyainya, dan faktor luar, perkembangan dan tuntutan zaman (sebut saja pengaruh globalisasi). Mencermati perkembangan globalisasi yang kian marak ini, bisa dipastikan banyak orang yang "meyakini" bahwa peran pesantren, madrasah dan sekolah Islam dalam menyebarkan Islam di bumi Nusantara ini. Hanya saja, tidak banyak dari mereka yang mengetahui kapan pesantren pertama kali lahir. Para sejarawan pun tidak sepakat mengenai awal berdirinya pesantren. Baik keberadaan pesantren, madrasah dan sekolah Islam tidak bisa dilepaskan dari penyebaran Islam di Indonesia.

Proses globalisasi yang terus menemukan momentumnya sejak dua dasawarsa menjelang millenium baru telah memunculkan wacana baru dalam berbagai lapangan kehidupan literatur akademik, media massa, forum-forum seminar, diskusi, dan pembahasan dalam berbagai lembaga. Penggunaan istilah "globalisasi " semakin meluas termasuk di Indonesia, penggunaan istilah lain seperti "kesejagatan" tidak cukup reperesentatif untuk menampung semua makna dan nuansa yang tercakup dalam istilah "globalisasi"

"Globalisasi" adalah kata yang digunakan untuk mengacu kepada "bersatunya" berbagai negara dalam globe menjadi satu entitas. Secara denotatif "globalisasi " berarti perubahanperubahan struktural dalam seluruh kehidupan negara bangsa yang mempengaruhi fundamen-fundamen dasar pengaturan hubungan antar manusia, organisasi-organisasi sosial, dan pandangan pandangan dunia (Azyumardi Azra, 2007 : 6). Beberapa pesantren yang awalnya salafiyah, hanya mengajarkan kitab-kitab kuning dan bertujuan mencetak kader ulama', kemudia berubah dengan menawarkan sekolah formal, seperti madrasah atau sekolah, adalah bukti pesantren mengalami perubahan orientasi.

Perubahan ini terutama sekali dipengaruhi oleh faktor kiyai , yang dalam pesantren tradisional adalah pemilik sekaligus pemimpin absolut dari pesantren tersebut. Persinggungan kiyai-kiyai tradisional dengan budaya luar, baik melalui ibadah haji maupun kegiatan lainnya, turut menyumbangkan gagasan pembaruan yang dilakukan kiyai. Para Kiyai yang sudah "modern" itu beranggapan bahwa santri tidak cukup dibekali dengan pengetahuan agama semata, melainkan harus memiliki tambahan pengetahuan yang bermanfaat bagi kehidupannya ketika terjuan dan kembali kemasyarakat

Beberapa pesantren yang membuka sekolah dan madrasah formal, selain karena gagasan pembaruan kiyai, juga disebabkan karena tuntutan zaman. Oleh karenanya pesantren-pesantren yang membuka sekolah dan madrasah sedikit banyak dipengaruhi oleh 
kebutuhan masyarakat tentang tenaga profesional yang memiliki akhlak mulia. Pada awal kemerdekaan, negara banyak membutuhkan pegawai negeri sipil. Untuk memenuhi kebutuhan itu, pesantren tidak tinggal diam. Pendirian sekolah dan madrasah adalah bentuk respon pesantren atas kelangkaan pegawai negeri sipil. Pesantren berharap, stock PNS dari lulusan pesantren memiliki kelebihan di bidang akhlaknya dibanding lulusan dari sekolah biasa (Amin Haedari, 2007: 34).

Dalam perkembangan modern seperti saat ini, tuntutan peran pesantren semakin kompleks. Problem-problem sosial ekonomi yang terjadi di masyarakat, seperti masalah disintegrasi, kemiskinan, kemunduran akhlak sudah semakin terbuka dan merajalela di masyarakat. Pesantren diharapkan tidak saja mampu menyelesaikan masalah-masalah yang terkait dengan faham keagamaan, tetapi juga diharapkan dapat terlibat menyelesaikan masalah-masalah sosial tersebut.

Sejauh pengamatan penulis, pesantren yang di dalamnya ada madrasah dan sekolah Islam memiliki peluang dan kesempatan untuk terlibat aktif dalam menuntaskan problem-problem sosial tersebut. Apalagi pesantren tersebut memiliki karakter sosial dan kedekatan emosi dengan masyarakat karena sifat egalitar dan kesahajaannya yang memungkinkannya dapat berinteraksi secara intensif dengan masyarakat (misalnya salah satu contoh pesantren Sunan Pandanaran yang bertempat Dusun Candi, Sardonoharja, Ngaglik, Sleman, ) setiap sebulan sekali tepatnya pada setiap Kamis wage terlihat bagaimana tumpah ruah masyarakat dari berbagai Kecamatan bahkan Kabupaten di sekitar Daerah Istimewa Yogyakarta juga luar Propinsi mendatang pengajian Mujahadah Akbar yang contennya adalah syiar Islam dan sekaligus media komunikasi antar masyarakat muslim muslimah dalam rangka mencari solusi penyelesaian problem-problem sosial kehidupan yang semakin "menghimpit" terutama pasca kenaikan BBM ini dan penyadaran diri sebagai hamba atau kholifah kepada sang Kholiq

Dengan demikian, esensi peran strategis pesantren, madasah dan sekolah Islam ada dua pokok, yaitu mencetak kader ulama' yang mendalami ilmu agama dan pada saat yang sama mengetahui, terampil, dan peduli terhadap persoalan keummatan. Pesantren adalah tempat untuk mencetak kader "faqih fi 'ulum al- din dan faqih fi mashalih al-ummah" . Lulusan Pesantren diharapkan baik agamanya dan pandai menghadapi persoalan umat.

Dengan peran semacam ini, dimungkinkan pesantren, 
madrasah dan sekolah Islam terlibat maksimal dalam membangun bangsa ini . Melalui pesantren, madrasah dan sekolah Islam, para santri atau siswa belajar ilmu-ilmu agama dan ilmu sosial yang dibutuhkan masyarakat. Bahkan seterusnya pesantren menjadi lembaga pengkaderan bagi santri atau siswa yang kelak siap terjun di masyarakat.

Peran pesantren yang demikian ini sesungguhnya tidak asing lagi di kalangan dunia pesantren, karena dunia pesantren sudah tahu betul bahwa setiap manusia yang ingin sukses harus menguasai ilmu dan inovatif sebagaimana pesan Rasul Muhammad SAW tentang Etos Kerja dalam hadis berikut ini:

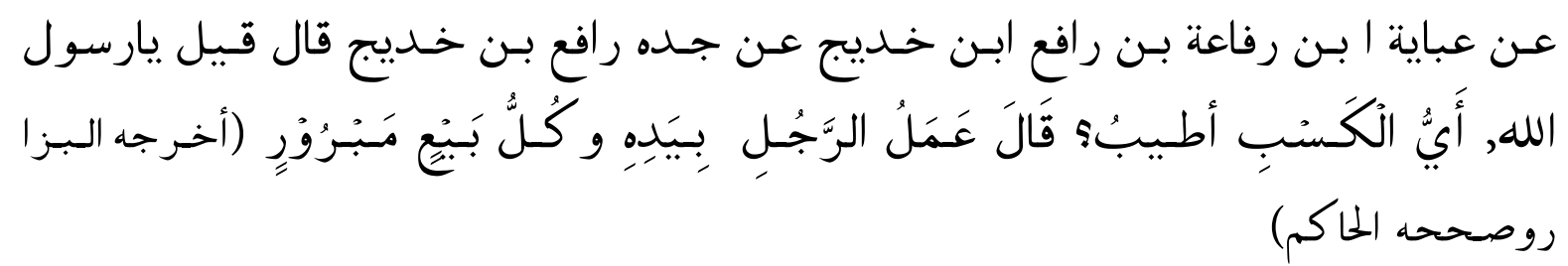

Artinya: Dari Rifa'ah bin Rafi' ra., bahwasanya Rasulullah saw pernah ditanyai usaha yang paling baik. Beliau menjawab : yaitu amal usaha seseorang dengan tangannya sendiri dan semua jual beli yang bersih. (HR. Al-Bazzar dan dinilai shahih oleh al-Hakim) (Sahih Bukhari; 800)

Pesan Nabi berikutnya yang tidak kalah pentingnya adalah "barang siapa ingin sukses dalam urusan duniaharus memiliki ilmunya, sama halnya ingin sukses akhirat, dan barang siapa ingin menghendai keduanya, baginya juga menguasai ilmu dunia dan akhirat

Mencermati peran strategis pesantren, madrasah dan sekolah Islam di Indonesia seperti tersebut di atas, diharapkan dapat mengembalikan kejayaan umat Islam yang pernah menyinari dunia dengan ilmunya. Saat itu, Islam menjadi pusat peradaban di mana di tempat lain sedang mengalami kegelapan. Saat negara dan bangsa lain terkungkung dalam kemunduran dan kemiskinan, Islam maju meninggalkan negara dan bangsa lain. Kemajuan ini diperoleh karena perhatian serius Islam terhadap pengembangan ilmu pengetahuan, disamping tetap mempertahankan ilmu agama

Saat itu , tidak ada dikhotomi ilmu agama dan umum. Para cendekiawan muslim mempelajari dan menguasai kedua ilmu ini secara bersamaan. Ambil saja contoh, ulama Ibnu Rusyd yang tidak saja mendalam dalam bidang fikih, tetapi juga piawai dalam bidang filsafat. Ibnu Syina, ahli agama sekaligus ahli bidang kedokteran. 
Bukunya tentang kedokteran "Althib", tidak saja dirujuk oleh ilmuwan dan ahli di Barat, tetapi juga menjadi inspirasi bagi perkembangan dunia kedokteran modern. Muhammad Abduh, ahli bidang sosiologi sekaligus pakar bidang agama dan masih banyak lagi sederet cendekiawan muslim dalam berbagai bidang : matematika, bahasa, ilmu tanah, pertanian dan sebagainya yang ikut mencerahkan dunia (Amin Haedari, 2007: 36).

Islam mengalami kemunduran saat terkungkung dengan taklid dan mengabaikan ilmu pengetahuan. Ketika Islma meninggalkan ilmu pengetahuan dan mengalami kejumudan, negara dan bangsa lain bangkit dari keterpurukan . Akhirnya, kini dalam beberapa kurun waktu Islam mengalami keterpurukan. Oleh karena itu sudah saatnya pesantren, madrasah dan sekolah Islam mengangkat keterpurukan bangsa Indonesia khusunya dan umat manusia pada umumnya saat ini. Peran-peran madrasah dan pundi-pundi keilmuan seperti Baitul Hikmah pada zaman kejayaan Islam, yang telah memberi sumbangan berarti bagi kemajuan Islam, dapat ditransfer oleh pesantren, madrasah dan sekolah Islam untuk dapat diterapkan saat ini, sehingga ketiga lembaga Islam tersebut menjadi laboratorium ilmu pengetahuan agama dan pusat riset kegiatan ilmiah

Dengan menjadi pusat riset ilmu pengetahuan, prediksi Nurcholis Madjid (Nurcholis Madjid, 1977), tentang Universitas Tebuireng, Universitas Tremas, Universitas Lirboyo, dan Universitas Pesantren lainnya di Indonesia dapat terwujud. Hal ini cukup beralasan , karena kemajuan Islam masa pertengahan, terutama ditopang oleh budaya riset ilmu pengetahuan. Apalagi pesantren yang jumlahnya puluhan ribu, jika mampu menjadi pusat riset ilmu pengetahuan , maka pengaruh sekaligus perannya akan melebihi Baitul Hikmah dan dampaknya dapat meluas ke seluruh dunia. Dengan begitu, kemajuan Islam dapat diraih kembali. Lebih dari itu peran pesantren yang utama adalah lulusannya diharapkan memiliki kelebihan dari sisi akhlakul karimah, karena pesantern sudah semestinya menjadi pengawal bagi akhlak yang terpuji ini.

Di akhir tulisan sederhana ini penulis pertanyaan : "mungkinkah pesantren, madrasah dan sekolah Islam "menjadi besar? pertanyaan ini tidak untuk dijawab mungkin atau tidak, tetapi harus dijawab dengan kata HARUS . Mengapa harus, karena pesantren , madrasah dan sekolah Islam harus menjadi besar seiring dengan ekspektasi masyarakat yang semakin besar terhadap pesantren, madrasah dan sekolah Islam, terutama setelah pendidikan yang lain tidak 
mampu memenuhi tuntutan mental dan akhlak yang diharapkan masyarakat.

Pesantren dimulai dengan menetapkan visi dan misi (tujuan ) yang tepat, yaitu mencetak kader yang ahli di bidang agama dan mumpuni dalam urusan sosial, kemudian bersma pemerintah membangun kemitraan untuk merumuskan kebijakan dan program pengembangan pesantren, madrasah dan sekolah Islam di masa depan. Saran sederhana misalnya dengan mengacu kepada sistem mutu sekolah formal yang tersandarisasi dan aspek manajerial yang berbasis industri ( dengan tetap mengacu kepada Qur'an Hadis ).

\section{DAFTAR PUSTAKA}

Agus Maulana,MSM dalam Pearce Robinson,1997, Manajemen S trategik,Formulasi,Implementasi dan Pengenalian, Binarupa Aksara:Jakarta

Amin Haedari, dalam Jurnal Mihrab Vol. II, no 1 Juli 2007

Amin Haedari dalam Jurnal Pondok Pesantren Mihrab, vol. II No. 1 Juli 2007 ,

Mas'ud Abdurrahman; Dinamika Pesantren dan Madrasah;2002, Yogyakarta: Pustaka Pelajar

Mastuhu, 1999, Memberdayakan Sistem Pendidikan Islam Ciputat : PT Logas Wacana Ilmu

Maksum, 1999, Madrasah Sejarah dan Perkembangannya, PT Logas Wacana Ilmu

Mifathul Haq,2002,Bakti, No.130.Th XI

Azyumardi Azra dalam Jurnal Pondok Pesantren Mihrab, vol. II No. 2 November 2007

Nurcholis Madjid, 1977, Bilik-bilik Pesantren, sebuah potret perjalanan; Jakarta:Paramadina. 